\title{
Modifications on Leaf Anatomy of Coffea arabica caused by Shade of Pigeonpea (Cajanus cajan)
}

\author{
Heverly Morais ${ }^{1 *}$, Moacyr Eurípedes Medri ${ }^{2}$, Celso Jamil Marur ${ }^{3}$, Paulo Henrique \\ Caramori $^{3}$, Ana Maria de Arruda Ribeiro ${ }^{4}$ and José Carlos Gomes ${ }^{5}$ \\ ${ }^{1}$ IAPAR; Área de Ecofisiologia; Rod. Celso Garcia Cid, Km 375; C. P. 481; 86001-970; Londrina - PR - Brazil. \\ ${ }^{2}$ Universidade Estadual de Londrina; Centro de Ciências Biológicas; Departamento de Biologia Animal e Vegetal; \\ C. P. 6001; 86051-990; Londrina - PR - Brazil. ${ }^{3}$ IAPAR; Área de Ecofisiologia; Londrina - PR - Brazil. \\ ${ }^{4}$ Universidade Estadual de Londrina; Centro de Ciências Agrárias; Departamento de Agronomia; Londrina - PR - \\ Brazil. ${ }^{5}$ IAPAR; Área de Biometria; Londrina - PR - Brazil
}

\begin{abstract}
Modifications on leaf anatomy in Coffea arabica shaded with pigeonpea (Cajanus cajan), compared to cultivation under full sun, were assessed. The leaves fully exposed to sunlight presented thicker cuticles and cellular walls, narrower epidermis cells, palisade parenchyma with longer cells, thicker lacunar parenchyma, fewer intercellular spaces and a larger stomata number. Leaves under dense shade presented a narrower cuticle and cellular wall; a mesophyll with smaller volume, but with larger intercellular spaces; and epidermis with thicker cells and a smaller stomata amount, surrounded by subsidiary cells of smaller dimensions. Plants grown under full sunlight presented higher values of net photosynthesis. The results evidenced that the species $\mathrm{C}$. arabica has a wide range of phenotypic adaptation to changes in the radiation intensity.
\end{abstract}

Key words: Coffee, shading, morphology, physiology, agroforestry

\section{INTRODUCTION}

The Coffea arabica species originated under the shade of tropical forests (Kumar and Tieszen, 1980). Its adaptation to shade conditions favored cultivation in agroforestry systems, a widespread practice in Latin America with satisfactory results in soil and microclimate improvement and preservation of the ecosystem. Nowadays, coffee is economically grown in Brazil under full sun, due to its adaptation to such conditions and higher productive capacity based on intensive chemical fertilization.

Plants adapt themselves according to the existent average conditions of radiation during a morphogenesis. The phenotypic differentiation of organs and tissues is usually irreversible (Larcher, 2000). An increasing interest on coffee adaptation to different light intensities has motivated several studies on the anatomy of these plants. It is well known that plant evolving adaptations to different habitats, especially concerning water availability, may be related to different structural characteristics (Larcher, 2000).

Taking into account plant-water relationships, plants are usually classified as xerophytes (adapted to dry habitats); mesophytes (require water availability in the soil and atmosphere); and hydrophytes (either require a great amount of humidity, or grow partially or totally submerged in

*Author for correspondence 
water). The peculiarities distinguishing plants that belong to different habitats are clearly evident in the leaves. The xeromorphic characteristics are reinforced by differences in genetic expression among species. However, environmental factors may induce a certain level of xeromorphy among leaves of the same species, normally mesomorphs. This occurs because the adaptation to different hydric conditions is strictly related to the radiation and temperature secondary effects. Therefore, leaves that develop under higher light intensities show a higher level of xeromorphy than those protected from light. During the development stage, this reaction is responsible for the differentiation basis between leaves exposed to the sun (sun leaves) and leaves grown under shade (shade leaves) (Esau, 1974). This results in anatomical differences, and includes, to a certain extent, metabolic differences (Coll et al., 1980). Sun leaves tend to be smaller but thicker, with a more differentiated palisade tissue than leaves which develop under the shade (Wylie, 1949; Medri and Perez, 1979; 1980; 1983; Larcher, 1984). Voltan et al. (1992) found many anatomical evidences of the great adaptability of coffee plant leaves submitted to different radiation intensities under artificial shading.

These structural modifications aim at the optimization of the capture of the available solar radiation, which is the main source of energy for photosynthesis. Natural shading is one of the most important factors in intercepting radiation, because the density and architecture of the tallest species tree top determine the solar energy fraction to be captured by the subjacent plants and converted into organic material. In the anatomical characteristics of the leaves, such as how easily $\mathrm{CO}_{2}$ may spread in intercellular spaces, and the form and distribution of the stomatic apparatus, lie the causes of different photosynthetic capacities. These differences are the basis for having more productive plants. Therefore, the answer about how to reduce or eliminate shading is due in part to the anatomical structures.

A few anatomical studies have been developed on coffee plant grown in vases, under artificial shading conditions (Voltan et al., 1992; Larcher, 1984) and in nurseries (Paiva and Guimarães, 2001); however, there are no reports of studies in field conditions under natural shading. This study aimed at evaluating the anatomy of Coffea arabica leaves under the shade of pigeonpea (Cajanus cajan) and under full-sun conditions.

\section{MATERIALS AND METHODS}

Plants of Coffea arabica cultivar IPR 99 were planted in $2.50 \mathrm{~m} \times 0.70 \mathrm{~m}$ spacing. The crop was pruned at $30 \mathrm{~cm}$, after a severe frost. The experiment used a total area of $6,000 \mathrm{~m}^{2}$, divided in two sub-areas containing coffee plants grown under full sun and coffee plants intercropped with "giant pigeonpea" (Cajanus cajan), cultivar IAPAR PPP-832. Pigeonpea was sown at a density of 3-plants/linear $\mathrm{m}$, reaching its maximum vegetative growth at $4 \mathrm{~m}$ height when it completely covered the coffee plants. The pigeonpea was pruned at $60 \mathrm{~cm}$, started growing again and reached its maximum height (about $4 \mathrm{~m}$ ). The characterization of the shading density was done by measuring the global solar radiation that reached the top of the coffee plants under the shade and full-sun, with LI-COR pyranometers (model LI200X) coupled to a micrologger.

For the anatomical studies, ten leaves from the second leaf pair of the plagiotropic branch from the apex were randomly chosen in each treatment. Only leaves positioned in the upper limit of the plant and facing north were collected, to prevent excess of variability due to environmental conditions. Leaf discs of $0.5 \mathrm{~cm}^{2}$ were extracted of the central region of each leaf and were submitted to the preparation of slides by the Johansen's Paraffin Method (1940). This procedure consisted of the fixation in F.A.A. 50 (formaldehyde, acetic acid and etilic alcohol), etilic alcohol washing, dehydration and clarification in an alcoholic-xylol series.

Finally, the cuts were blocked in paraffin and 10 $\mu$ m-thick transversal sections were taken with a manual microtome-rotational. These sections went through stages of pasting in slides with Haupt's adhesive (Johansen, 1940), distensions in a heated slide and coloring by the combination of astra blue and basic fucsin, and they were finally fixed in Canada balsam. For the analysis of the transversal cuts, five measurements of each individual were performed using a micrometric ocular. The thickness of the following structures was evaluated: cellular wall and cuticle, abaxial and adaxial epidermis, palisade and lacunar parenchyma and leaf. The percentage of intercellular spaces was calculated with the gravimetric method (Medri, 1978), without the aid of the micrometric ocular. 




Figure 1 - Monthly distribution of Global Solar Radiation in 2001 in shaded coffee plants (open circles) and coffee plants under full-sun (closed circles). The columns correspond to the percentage of global radiation interception by pigeonpea.

The number of stomata was evaluated by preparing slides from the nitrocellulose impression (colorless enamel) in the abaxial epidermis of the leaves, using pellicles extracted from the median third. The stomata counting were done in five fields from each leaf. In order to characterize stomata length, five leaves from each treatment were evaluated, and pieces of $0.5 \mathrm{~cm}^{2}$ were taken from their median region. These pieces went through the process of epidermis dissociation by Jeffrey's Mixture (chromic acid and nitric acid at $10 \%$ ) (Johansen, 1940), followed by coloring with a combination of astra blue and basic fucsin and fixation in slides. The length of ten stomata was measured in five different fields. All measurements were obtained with a clear-camera microscope containing a micrometric ocular. The photosynthetic rates of three coffee plants in each treatment were measured. Leaves from the second pair from the apex of plagiotropic branches fully exposed to sunlight were selected for measurements. Two leaves of each plant were used to measure the net photosynthesis with a portable system (LI-COR, model LI-6200 and gas analyser LI-6250). Data were submitted to mean comparison by Student's statistic “t”" test.

\section{RESULTS AND DISCUSSION}

Table 1 and Fig. 2 show that the coffee leaves grown under full sun presented thicker cellular wall plus cuticle, both in the abaxial and adaxial faces. This is related to the role they play in the isolation of the mesophyll from excessive heat. In general, in both treatments the cuticle considered individually did not present any differences in thickness, with values around $2.5 \mu \mathrm{m}$. Thick cellular walls, especially in the epidermis, and thick cuticle are frequently expressed in xerophytes plants, but the cuticle thickness may vary (Esau, 1974). In a transversal section (Fig 2) we saw that the epidermis was composed of only 
one layer of cells in both faces, and the shading caused a significant increase in the thickness of these cells (Table 1). When exposed to frontal view (Fig 3), the epidermic cells from shaded coffee plants showed larger surface area with an increase of $22 \%$ in the adaxial face and $17 \%$ in the abaxial face, and an increase in their dimension. The alterations found in leaves with different light exposures could be attributed to different levels of growth regulators. The auxins have the role of making cellular distensions possible, and as a molecular characteristic, they are able to migrate to less illuminated regions or faces. As they concentrate in shaded regions, they are able to distend the cells more easily (Medri and Perez, 1979). As a result, more illuminated leaves strongly concentrate their auxins inside the mesophyll, different from what occurs in a shaded leaf, whose auxins would be diluted through all the leaf, including the mesophyll and the epidermis. This different distribution of auxins is in great part responsible for the structural differences, allowing the distension of epidermic cells in shade leaves (Medri and Perez, 1980).

The coffee plant leaves mesophyll was dorsiventral and clearly differentiated between palisade and lacunar parenchyma. The first was constituted of elongated and densely grouped cells, perpendicularly disposed to the adaxial surface of the leaf (Fig 2). The lacunar parenchyma cells were loose with irregular shapes and a predominantly horizontal continuity parallel to the leaf surface (Fig 2). Table 1 shows that full-sun coffee plant leaves had a thicker palisade and lacunar parenchyma. The palisade parenchyma cells in these plants were more elongated while shaded coffee plants have shorter cells (Fig 2). This characteristic was very similar to the ones of sugar beet leaves, in which the shape of the mesophyll cells was associated to the leaf thickness (Esau, 1974). Cutter (1978) pointed that the anatomical structure in mesophytes differs according to light intensity, resulting in the socalled sun and shade leaves in the same species. The shade leaves were thinner with shorter and less differentiated cells in the palisade parenchyma, and also presented the lacunar parenchyma quite diffuse Medri and Perez (1980), attributed the increase in the mesophyll in sun leaves to auxins.

Table 1 - Amount and dimension of Coffea arabica leaves internal structures under the shade of pigeonpea and exposed to the sun

\begin{tabular}{lcccc}
\hline Internal structures & $\begin{array}{c}\text { Shaded } \\
\text { coffee plants }\end{array}$ & $\begin{array}{c}\text { Coffee plants } \\
\text { under full } \\
\text { sun }\end{array}$ & t Value & Pr $>|\mathbf{t}|$ \\
\hline Cellular wall + adaxial cuticle thickness $(\mu \mathrm{m})$ & 4.50 & 5.45 & $-3.00 * *$ & 0.0035 \\
Cellular wall + abaxial cuticle thickness $(\mu \mathrm{m})$ & 2.50 & 3.40 & $-4.52 * *$ & $<0.0001$ \\
Adaxial epidermis thickness $(\mu \mathrm{m})$ & 22.65 & 19.25 & $4.97 * *$ & $<0.0001$ \\
Abaxial epidermis thickness $(\mu \mathrm{m})$ & 21.10 & 13.90 & $9.08 * *$ & $<0.0001$ \\
Palisade parenchyma thickness $(\mu \mathrm{m})$ & 50.30 & 78.60 & $-9.16 * *$ & $<0.0001$ \\
Lacunar parenchyma thickness $(\mu \mathrm{m})$ & 147.00 & 156.65 & $-2.46 *$ & 0.0156 \\
Intercellular spaces $(\%)$ & 22.91 & 16.10 & $8.32 * *$ & $<0.0001$ \\
Leaf thickness $(\mu \mathrm{m})$ & 248.05 & 277.25 & $-4.78 * *$ & $<0.0001$ \\
Stoma number $\left(\mathrm{mm}^{2}\right)$ & 138.37 & 208.47 & $-12.88 * *$ & $<0.0001$ \\
\hline
\end{tabular}

* significant at $\operatorname{Pr}<0.05, * *$ significant at $\operatorname{Pr}<0.01$

This plant growth regulator is found in abundance in the mesophyll of illuminated leaves, and plays an important role in tissue expansion. Such characteristics were also observed by Medri and Perez (1979) in Bertholletia excelsa, Medri and Perez (1980) in Hevea brasiliensis and by Medri 
and Martinez (1985) in Persea americana. Appezzato-da-Glória et al. (1997), while studying the Aristolochia melastoma species (a shade species) also verified these characteristics. The other species studied by these authors (Aristolochia arcuata, A. galeata, A. gigantea and A. triangularis) were fully exposed to sunlight, and presented a well-more developed and differentiated palisade parenchyma. The mesophyll has also been characterized by the abundance of intercellular spaces, mainly in the lacunar parenchyma. According to the results obtained, coffee leaves grown under full sun showed smaller intercellular spaces (Table 1; Fig 2). Mechanical reinforcements of leaves, represented by a great development of the mesophyll - common in xerophytes - are interpreted as structures that reduce the harmful effects produced by wilting (Stalfelt, 1956). On the contrary, the abundance of these spaces commonly found in shaded plants make light absorption easier and casualizes its direction, improving its way to the chloroplasts (Paiva and Guimarães, 2001). Table 1 showed that shaded coffee plants presented thinner leaves compared to those grown under full sun. This was basically due to the greater thickness of the mesophyll components under full sun. One of the xerophytic leaves characteristics is the elevated ratio volumesurface, that is, specific weight high values with small and compact leaves (Esau, 1974; Medri and Perez, 1983).



A

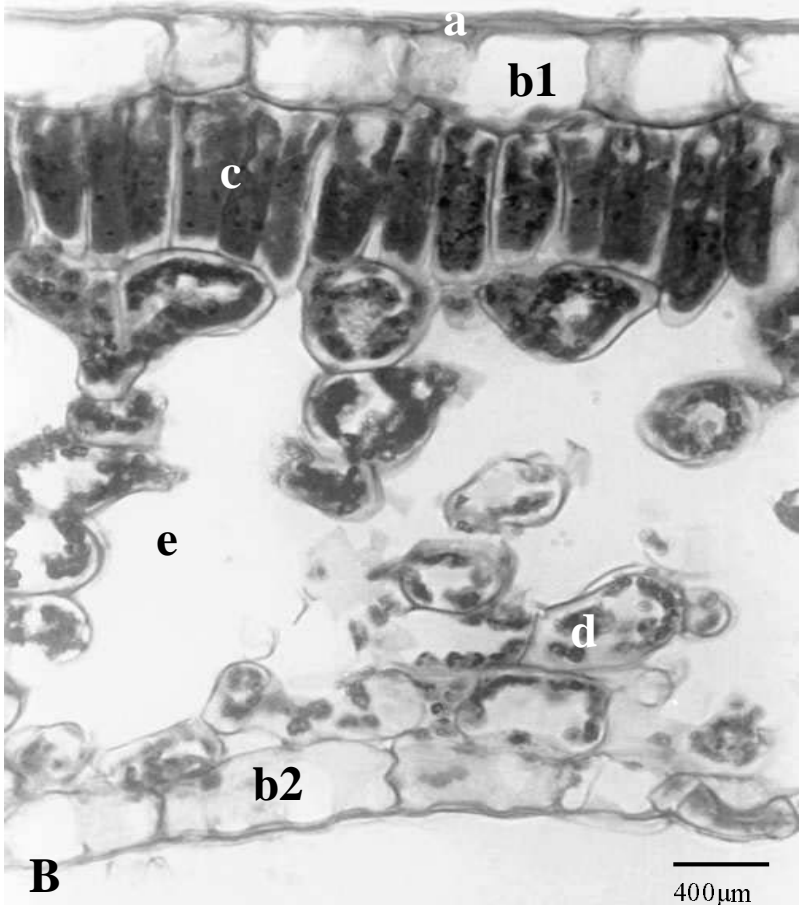

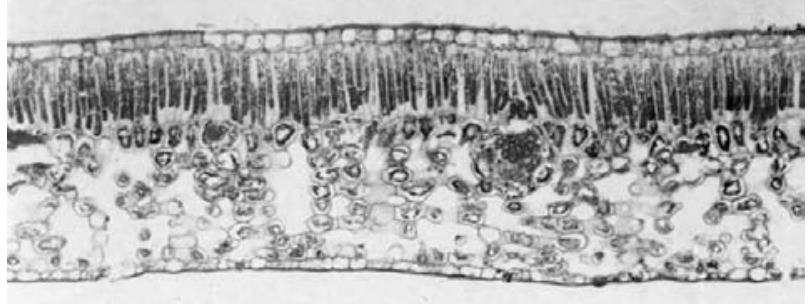

C

$\overline{100 \mu \mathrm{m}}$

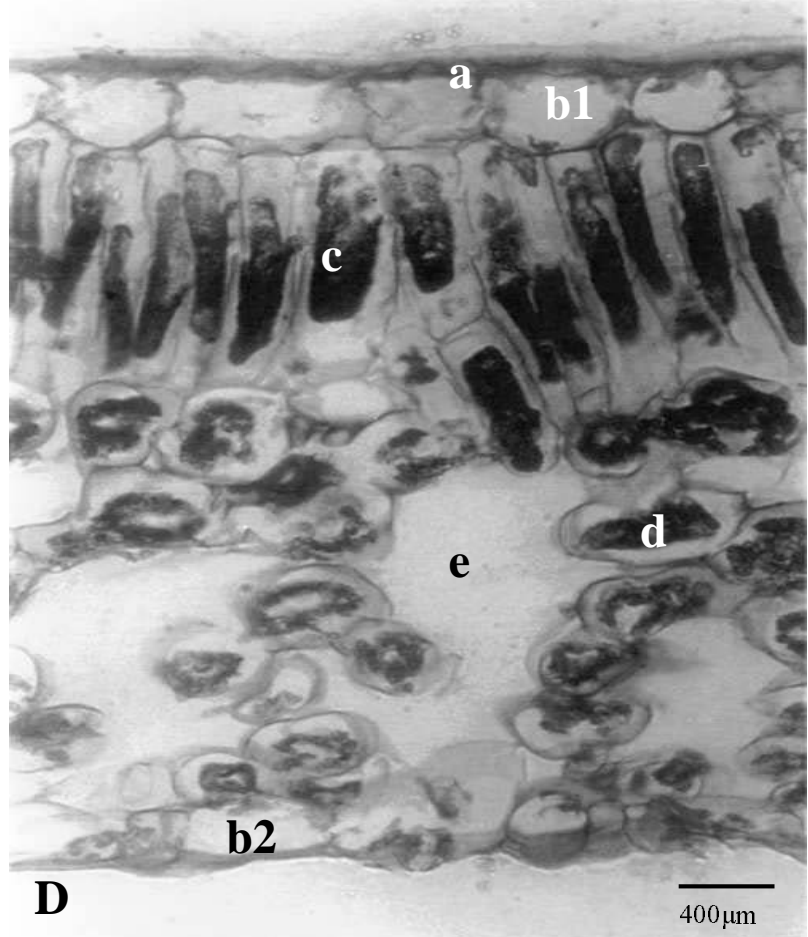

Figure 2 - Transversal section of a coffee plant leaf shaded with pigeonpea (A and B) and full-sun coffee plant (C and D). (a) Cellular wall + cuticle; (b1) Adaxial epidermis; (b2) Abaxial epidermis; (c) palisade parenchyma; (d) Lacunar parenchyma; (e) Intercellular spaces 

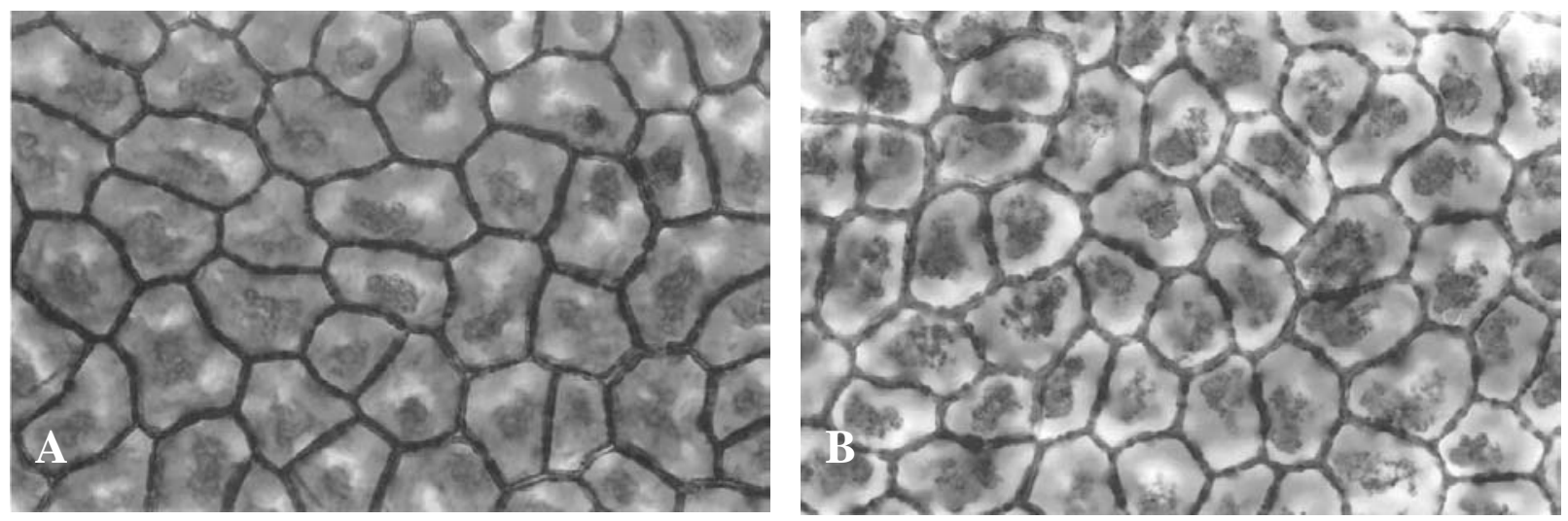

Figure 3 - Frontal view of the adaxial epidermis of the shaded coffee plant leaf (A) and under full sun (B).


es


$(-400 \mu \mathrm{m})$

Figure 4 - Front view of the abaxial epidermis of a shaded coffee plant leaf (A and B) and coffee plant under full sun (C and D). cs - subsidiary cells, es - stomata.

The stomata present in coffee leaves were paracytic (Fig 4), as also classified by to Metcalfe and Chalk classification (1950), and concentrated in the abaxial face. In a transversal section, the stomata were contained in the same level of the other epidermic cells (Fig 5). Table 1 and Fig. 4 
show an expressive difference in the number of stomata per leaf area unit between the treatments $(33.62 \%)$, with higher values in coffee plants grown under full sun. The length of these stomata in both treatments varied from 22.5 to $35 \mu \mathrm{m}$, without significant difference between treatments. In general, the number of stomata per leaf area unit was higher in dry conditions than under humid conditions. This was mainly attributed to a reduction in the leaf expansion of plants that were under dry conditions, but the number of stomata, considered as a percentage of the number of epidermic cells (the stoma index), also tended to be smaller in plants with a good water supply (Sutcliffe, 1980). These anatomical variations in coffee plants under natural shading agreed with the ones obtained by Voltan et al. (1992) and Paiva and Guimarães (2001) in coffee plants grown under artificial shading, and with other species studied and described by several authors (Larcher, 1984; Esau, 1974; Wylie, 1951).

Another difference observed in the internal structure of coffee plant leaves is the size of the subsidiary cells. Figs. 4C and 4D showed that the subsidiary cells of coffee plant leaves grown under full sun were bigger. The differential volume might be involved in the opening and closing of the stomatic pore. The main factors affecting this opening and closing were light, turgescence and temperature. The oscillations of these factors during the day were more expressive in coffee leaves under full sun, therefore the opening and closing of the stomata was more intense in sun leaves. Stomata of shaded coffee leaves tended to remain open all day long (Alvim, 1958).

Based on this study, it could be stated that the histologic structures of Coffea arabica leaves have a great phenotypic adaptation to solar radiation - they adapt their shape according to the incidence of light.

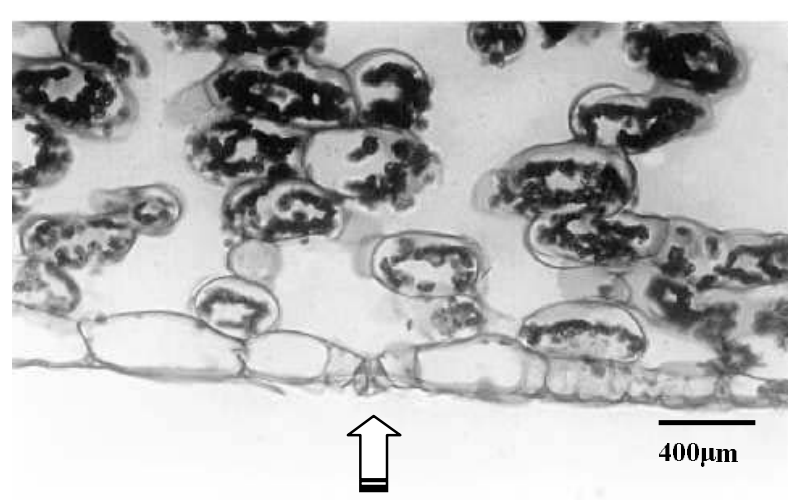

Figure 5 - Transversal section of a shaded coffee plant leaf. Detail showing the stoma (indicated by the arrow) in the same level of the abaxial epidermis.

The plants grown under full sunlight presented higher values of net photosynthesis (Table 2). These differences were due to metabolic and anatomic characteristics of the leaves (larger dimensions of subsidiary leaves and a larger number of stomata), and the mesophyll (greater density), which were closely and positively related to the photosynthesis process. According to Oroszco-Castaño and Cassalett-Dávila (1974), the coffee plant seemed to adapt anatomical resources that allowed an increase in its photosynthetic efficiency as the light amount increases. As a consequence of these structural modifications and a more active metabolism, the plants that were adapted to greater irradiance intensities would probably provide higher productions.

Table 2 - Net photosynthesis, in $\mathrm{mg} \mathrm{CO} \mathrm{Cm}^{-2} \mathrm{~min}^{-1}$, of Coffea arabica leaves under the shade of pigeonpea and exposed to sunlight

\begin{tabular}{rccccc}
\hline Hour & Shaded coffee plants & Coffee plants under full sunlight & $\mathbf{t}$ Value & $\operatorname{Pr}>|\mathbf{t}|$ \\
\hline $8-9$ & 4.42 & 8.51 & $4.05^{*}$ & 0.0155 \\
$9-10$ & 7.34 & 9.93 & $2.02^{\mathrm{ns}}$ & 0.1138 \\
$10-11$ & 8.20 & 9.79 & $2.14^{\mathrm{ns}}$ & 0.0992 \\
$11-13$ & 5.67 & 9.59 & $3.80^{*}$ & 0.0191 \\
$13-15$ & 5.67 & 9.08 & $2.92^{*}$ & 0.0432 \\
\hline
\end{tabular}

* significant at $\operatorname{Pr}<0.05$

${ }^{\text {ns }}$ no significant at $\operatorname{Pr}<0.05$ 


\section{ACKNOWLEDGEMENTS}

The authors are thankful to IAPAR, UEL and CNP \& D Café for providing facilities and financial support for the analyses.

\section{RESUMO}

Adaptações de plantas da mesma espécie aos diferentes habitats, constituem a base da diferenciação entre folhas a pleno sol e folhas sob sombra e estão associadas a características anatômicas distintas. Para caracterizar tais mudanças em cafeeiros cultivados sob sombra de guandu (Cajanus cajan) e a pleno sol, em Londrina, PR, foram realizadas avaliações de modificações ocorridas na anatomia foliar. As estruturas internas avaliadas foram: parede celular e cutícula; epiderme; mesofilo (parênquima paliçádico, parênquima lacunoso e espaços intercelulares) e estômatos. Para todas as variáveis avaliadas observaram-se diferenças anatômicas entre folhas expostas ao sol e à sombra. As folhas expostas ao sol apresentaram cutículas e paredes celulares mais espessas, células da epiderme mais estreitas, parênquima paliçádico com células mais alongadas, parênquima lacunoso espesso e com poucos espaços intercelulares e maior número de estômatos. Folhas sob condições de denso sombreamento apresentam menor espessamento da cutícula e da parede celular; mesofilos com menores volumes, porém com maiores espaços intercelulares; epidermes com células mais espessas e estômatos em menor quantidade, envoltos por células subsidiárias de menores dimensões. Plantas cultivadas a pleno sol apresentam maiores taxas fotossintéticas. Assim, Coffea arabica caracteriza-se como uma espécie com grande amplitude de adaptação fenotípica às mudanças na intensidade de radiação solar.

\section{REFERENCES}

Alvim, P. T. (1958), Recientes progresos em nuestro conocimiento del árbol de café. I Fisiologia. Coffee and Tea Industries, 81 : (11), 56-70.

Appezzato-da-Glória, B.; Capellari Jr. and Silva, A. M. (1997), Anatomia foliar de cinco espécies de Aristolochia (ARISTOLOCHIACEAE) do Estado de São Paulo (Brasil). Arquivos de Biologia $e$ Tecnologia, 40 : (1), 107-120.
Coll, J. B.; Rodrigo, G. N.; García, B. S. and Tamés, R. S. (1980), Fisiología Vegetal. Pirámide S.A, Madrid.

Cutter, E. G. (1978), Plant Anatomy. Part I: Cells and Tissues. Edward Arnold, England.

Esau, K. (1974), Anatomia das plantas com sementes. Tradução: Berta Lange de Morretes. Edgard Blücher, Brasil.

Johansen, D. A. (1940), Plant microtechnique. McGraw-Hill, USA.

Kumar, D. and Tieszen, L. L. (1980), Photosynthesis in Coffea arabica. Effects of light and temperature. Experimental Agriculture, 16 : (1), 13-19.

Larcher, W. (1984), Okologie der Pflanzen. German : UTB.

Larcher, W. (2000), Ecologia Vegetal. São Paulo : RiMa. [Tradução de Carlos H. B. A. Prado].

Medri, M. E. (1978), Comparação anatômica entre folhas diplóides e poliplóides do híbrido Hevea brasiliensis x Hevea benthamiana. Acta Amazônica, 8 : (4), 565-575.

Medri, M. E. and Martinez, M. M. (1985), Alguns aspectos da anatomia ecológica de Persea americana Mill e interpretações fisio-ecológicas. Semina, Euel, $6:$ (3), 140-146.

Medri, M. E. and Perez, E. L. (1979), Ecofisiologia de plantas da amazônia: anatomia foliar e ecofisiologia de Bertholletia excelsa Humb. and Bonpl. (castanhado- pará). Acta Amazônica, 9 : (1), 15-23.

Medri, M. E. and Perez, E. L. (1980), Aspectos da anatomia ecológica de folhas de Hevea brasiliensis Mell. Arg. Acta Amazônica, 10, 463-493.

Medri, M. E. and Perez, E. L. (1983), Quantificação e uso de caracteres anatômicos e fisiológicos de folhas na determinação da eficiência hídrica em clones de Hevea. Acta Amazônica, 13, 261-288.

Metcalfe, C. R. and Chalk, L. (1950), Anatomy of the Dicotyledons. England : Clarendon Press.

Orozco-Castaño, F. J. and Cassalett-Dávila, C. (1974), Caracteristicas anatomicas de las hojas y su relación com el posible ciclo fotosintetico en cafe. Cenicafe, 25 : (4), 104-112.

Paiva, L. C. and Guimarães, R. J. (2001), Efeitos dos níveis de irradiância sobre a anatomia foliar de mudas de cafeeiro (Coffea arabica L.). Congresso Brasileiro de Pesquisas Cafeeiras., 27, 110-112.

Stalfelt, M. G. (1956), Morphologie und anatomie des Blattes als Transpirationsorgan. Hand buch der pflanzephysiologie, 3, 324-341.

Sutcliffe, J. F. (1980), As plantas e a água. São Paulo : EDUSP.

Voltan, R. B. Q.; Fahl, J. I. and Carelli, M. L. C. (1992), Variações na anatomia foliar de cafeeiros submetidos a diferentes intensidades luminosas. Revista Brasileira de Fisiologia, 4 : (2), 99-105. 
Wylie, R. B. (1949), Differences in foliar organization among leaves in four locations in the crown of an isolated tree (Acer platonoides). Iowa Academy of Science Proceedings, 56, 189-198.

Wylie, R. B. (1951), Principles of foliar organization shown by sun-shade leaves, from ten species of deciduous dicotyledonous trees. American Journal of Botany, 38 : (5), 355-361.

Received: May 02, 2003;

Revised: October 16, 2003;

Accepted: July 07, 2004. 